\title{
Actors Perceptions on Challenges and Opportunities to Improve Street Vended Local Foods in Urban Ghana
}

\author{
Joyce Afua Sarpong Haleegoah"1*, Kofi Osei Akuoko², Peter Dwumah', Kofi Amoako Marfo3, \\ John Boulard Forkuor ${ }^{2}$, Benedicta Nsiah Frimpong1, Lydia Brobbey ${ }^{1}$ \\ ${ }^{1}$ CSIR-Crops Research Institute, Kumasi, Ghana \\ ${ }^{2}$ Department of Sociology and Social Work, Kwame Nkrumah University of Science and Technology (KNUST), Kumasi, Ghana \\ ${ }^{3}$ Millennium Development Authority, Accra, Ghana \\ Email: `haleegoahj@yahoo.co.uk
}

How to cite this paper: Haleegoah, J., Akuoko, K. O., Dwumah, P., Marfo, K. A., Forkuor, J. B., Nsiah Frimpong, B., \& Brobbey, L. (2020). Actors Perceptions on Challenges and Opportunities to Improve Street Vended Local Foods in Urban Ghana. Advances in Applied Sociology, 10, 435-453.

https://doi.org/10.4236/aasoci.2020.1011025

Received: October 2, 2020

Accepted: November 23, 2020

Published: November 26, 2020

Copyright (อ 2020 by author(s) and Scientific Research Publishing Inc. This work is licensed under the Creative Commons Attribution International License (CC BY 4.0).

http://creativecommons.org/licenses/by/4.0/ (c) (i) Open Access

\begin{abstract}
Street foods play an important role in the lives of urban residents in developing countries. Consequently, there has been a lot of research into the nutritional quality of street vended foods, and the safety and hygiene of these foods. Researchers in Ghana have focused not only on the safety and hygiene of street foods but also on the effectiveness of regulations of these foods. While these provide important knowledge base for policy and action, very little has been done on challenges to improve the quality of local street vended foods. This study presents qualitative data from key stakeholders (vendors, consumers, regulators), on the challenges and opportunities to improve the quality of street vended local foods. Results show several challenges that relate to the safety and hygienic conditions at preparation and sale environments, and issues with the local regulatory authorities, inadequate capital with its related challenges and insecure space for street food vendors. This research recommends that efficient and effective collaboration between all actors and relevant institutions could offer the vendors an opportunity and capacity to provide healthy, affordable and preferred local dishes of cultural value to consumers.
\end{abstract}

\section{Keywords}

Street Foods, Challenges, Opportunities, Food Vendors, Consumers, Local Authority

\section{Introduction}

Street vending is an important economic activity within the informal economy 
of most developing countries. As part of the numerous items vended on the streets, street foods are prominent, receiving significant attention from both researchers and policy makers. The number of street food vendors is expected to increase as urbanization increases in developing countries (FAO, 2007). Street foods relevance for urban dwellers is in the fact that they serve as a source of affordable, nutritious, accessible and locally acceptable foods for them. Again, street foods contribute to urban food security and are a source of income for many urban residents (Okojie \& Isah, 2014; Forkuor et al., 2016; FAO, 2016; Hiamey \& Hiamey, 2018).

Globally, a projected 2.5 billion people depend on street foods daily because of their affordability and accessibility (Bellia et al., 2016; FAO, 2016). Despite their importance, street food vendors, like other urban informal economy actors, face significant challenges from city authorities and urban regulators that limit their economic productivity and negatively affect their livelihoods. City authorities and some citizens perceive street vendors as a nuisance, especially in relation to their use of urban space. They are perceived as working in unrestricted and unsecured environments. They are often accused of not paying taxes, providing inferior products, creating nuisance in urban places, health and safety risks, and congestion in high traffic urban locations (FAO, 2007).

Within the food vending system is a pool of actors who interact continually to ensure that food is always available in public places. Apart from food vendors, other important actors who safeguard the persistence of street food vending are the local regulators, the Environmental Health Officers (EHOs) who make sure that food vendors have followed all safety and hygienic practices, and the consumers who patronize street foods, promoting their production and consumption (Haleegoah et al., 2016). These key actors interact to ensure that street foods are safe, nutritious, and affordable and are of local acceptance in urban areas. Street food vending thrives in urban areas but faces several challenges just as all street vendors. However, in providing safe, nutritious, affordable and locally accepted foods, the specific constraints that these actors face have received limited attention in literature.

Studying the perceptions of these actors is important because as food vendors provide foods, they are regulated by the EHOs and consumers are at the receiving end of the safe, nutritious, affordable and locally accepted foods. As a result of street foods' importance in the economy, identifying these challenges and the opportunities to improve their activities would inform policy on effective urban food governance, urban planning and to strengthen food vendors knowledge and ability to manage their food vending businesses.

The unprotected environment around which some street food vendors operate may compromise the safety and hygiene conditions of foods, giving room for unwholesome practices among food vendors. Chukuezi (2010) indicated that despite the importance of street foods in providing for people's food needs, they are associated with several health hazards and recommended health education for food vendors. Several other studies attest to this fact (Sackey et al., 2001; 
Mensah et al., 2002; WHO, 2006; Seferiadis, 2009). Due to the low educational level of most vendors, putting into practice hygiene and safety knowledge has been noted to be an issue (Seferiadis, 2009; Rheinländer et al., 2008). Obviously, low education of food vendors alone cannot be the only hindrance to proper food provisioning. Their interpersonal relationships with local authorities (Forkuor et al., 2016), capacity of the local authorities, institutional challenges (FAO, 2007; Monney et al., 2014), available policies to assist food vendors, the social classes' food vendors' deal with, and consumers' preferences, all may pose challenges to providing locally preferred, safe, nutritious and affordable SVLFs in the urban areas. How do actors perceive such challenges; how do these challenges influence food vending activities; and what are the opportunities to improve the provisioning of SVLFs in urban areas?

Just as all other street vendors, there is always conflict between local authorities and food vendors (FAO, 2007; Spire \& Choplin, 2018), though in general terms, some local authorities work with street vendors instead of against them (FAO, 2007). In their general interaction with food vendors, local authorities who regulate street food vending are challenged with several institutional issues and are even considered to have relegated their activities with food vendors to a source of revenue generation for the Metro, Municipal and District Assemblies (MMDAs) and not for safety and hygiene practices enforcement (Sefa-Dedeh et al., 2009). Consumers are concerned with the safeness of street foods (Haleegoah et al., 2015).

These challenges may also provide some opportunities for actors to ensure the provisioning of locally acceptable, safe, nutritious and affordable SVLFs. There is the need to understand the challenges that these specific food vendors face in their food provisioning for effective work together with local authorities, regulators of their activities to ensure that food vendors provide safe and healthy food for consumers. Such insights will provide useful information for guiding procedures to ensure effective and efficient street vending activities for the benefit of all actors.

This paper therefore aimed at outlining actors' characteristics, identifying their perceptions of challenges and opportunities of street vended local foods (SVLFs) and their importance in providing locally accepted, safe, nutritious and affordable street foods for public consumption. Although there are several varieties of foods and beverages sold in the streets (FAO, 2016), this paper focuses on three specific street vended local foods actors-Hausa koko, Waakye and Ga kenkey-in three major cities in Ghana. The choice of these SVLFs is because of their availability across Ghanaian streets, and their relatedness to some specific ethnic groups in the country. These foods are referred to as Street vended Local Foods (SVLFs) because they are sold in streets ready to be eaten, but are also associated with some specific ethnic groups in the country (Haleegoah et al., 2016). This association highlights the local aspect of these foods. While Hausa koko and Waakye are associated with the Hausa people, Ga kenkey is associated with the Ga people in Ghana. 


\section{Literature Review}

\subsection{Symbolic Interactionism Theoretical Perspective}

Symbolic interactionism is the theory that guided this paper. The theory states that people live in two environments; the natural and symbolic environments respectively. The two interacts and are characterized by shared meanings and values through symbols of the mind that are created through such interactions. Meanings constitute the shared interactions between people. Mere objects do not have meanings on their own unless attached to social actors. Thus, symbolic interactionism is a process of "interpretation of the action" (Aksan et al., 2009).

The theory thus examines meanings emerging from reciprocal interaction of individual food vendors in streets with other actors such as consumers and food regulators. SVLFs as part of the Ghanaian food culture, gain their meaning through individual actor's social interactions with other actors to be locally accepted, safe, nutritious and affordable. Actors in their interactions create their own perceptions of the challenges and opportunities to improve SVLFs.

\subsection{Challenges and Opportunities of Street Vended Local Foods}

Several studies on street food vending exist and most focus on the safety concerns and the microbial aspects of street foods and their vending (Mensah et al., 2002; Ayeh-Kumi et al., 2009; Ackah et al., 2011; Micah et al., 2012). Food vendors' knowledge and practices of food safety and hygiene are also widely studied (Okojie \& Isah, 2014; Monney et al., 2014). Monney et al. (2014), for instance found that overall compliance to food hygiene and safety principles was marginally good with difference between the study areas, Bibiani and Dormaa-Ahenkro in the Western and the now Bono regions of Ghana respectively. They identified the challenging aspects of the existing institutions and legislations to be weak institutional capacities, logistical constraints, in-consistent local by-laws and duplicating institutional responsibilities. These were the constraining issues challenging food vendors in their compliance to food hygiene and safety principles.

To enable local authorities as well as street food vendors and consumers take informed and data-driven actions towards the development of the sector, FAO (2016) conducted an extensive survey in Accra. It aimed at getting updated and policy-relevant information about the street food vending sector and looked at several areas of the sector including location and type of street food outlets, variety of foods sold, hygienic and safety conditions under which they were prepared, legal status of vendors, and economic dimension of the sector in Accra (FAO, 2016). Their results showed that most food vendors were females and most had at least basic education. Street food vending provided their main source of incomes for the care of their families and also as a means of employment for others. There were a variety of foods and beverages sold in streets in the city. It further indicated several contaminations with foods, though vendors 
had knowledge about safety and hygiene practices with several training conducted for them. Nevertheless, they did not address anything regarding challenges that these street food vendors faced and the opportunities they have, to ensure safe food provisioning.

Low education among other challenges was mentioned as the reason for some African women and street food vendors elsewhere in Asia to be self-employed with lower incomes compared to their male counterpart in the informal sector (FAO, 2016; Otoo et al., 2011; Habib, 2016). The study by Habib (2016), in the city of Dhaka, Bangladesh found that the major challenges for street food vendors to ensure food safety in their vending activities were lack of education, training and experience and lack of infrastructural support. In the Ghanaian literature, however, the FAO (2016) study indicated that several training had been organised for street food vendors in several cities. The challenge, however is food vendors' capacity to continually put into practice what they learned (Seferiadis, 2009; Rheinländer et al., 2008), which probably may be due to their low educational levels.

A study by Forkuor et al. (2016) looked at the male advantages, constraints and coping strategies in a female dominated street vending of traditional foods. They found out that male traditional food vendors faced some social ridicule in relation to the gender appropriateness of their chosen occupation, which is assumed to be a women's domain. Males however, enjoyed some gendered advantages at the expense of their female counterparts. Their work only focused on the constraints of males in the traditional female dominated occupation of food vending. The constraints of women vendors however get limited attention in literature.

Several challenges to street food vending and street vending in general have been identified. Some of these include inadequate knowledge and skills in business management (Osei Mensah et al., 2016), limited supply of skilled workers (Quader \& Abdullah, 2008), and limited access to credit and high cost of borrowing as well as high cost of production and lack of access to legal vending premises (Martey et al., 2013). Others are regulatory barriers from local authorities (FAO, 2007) and (Spire \& Choplin, 2018), and lack of collective action among vendors (Martey et al., 2013; Nicolò, 2012; Dorresteijn, 2014). Osei Mensah et al. (2016), studied the factors that constraint growth of street food vending enterprises in Ghana. They estimated the effect of food vendors self-reported constraints on the growth of their businesses. Their results showed that inadequate managerial skills and financial constraints had negative effects on the gross margin ratio between their baseline and follow-up periods. This literature generally addresses food vendors' constraints and their effect on the growth of their business not considering their provisioning of safe, nutritious, affordable and local dishes to consumers. This paper focuses on this with attention to some specific street food vendors (Hausa koko, Waakye and Ga kenkey vendors), EHOs and consumers of such foods in three cities in Ghana. 


\section{Research Methods}

This study used a qualitative multi-case study design, focusing on three local street vended foods as specific cases. Qualitative multi-case study design provides the requisite tools for researchers to study complex phenomena within their contexts. When this design is applied in the right context, it becomes a valuable method for research in the scientific community to develop theory, assess programs, and develop interventions. The qualitative case study is a research design which expedites an investigation of a phenomenon within its context relying on varied data sources. This avoids the tendency of viewing the issue under investigation through one lens but rather exploring various lenses which allow for multiple aspects of the phenomenon to be discovered and understood (Baxter \& Jack, 2008).

In-depth interviews and observations were used to collect data on the challenges and opportunities of food vendors, EHOs and consumers. Data was collected from two main streets in the three cities (Accra, Kumasi and Tamale) where any of the three foods were sold. A total of 54 food vendors comprising 12 Hausa koko, 19 Waakye and 23 Ga kenkey vendors were purposively selected for the study. Eighteen (18) willing consumers who patronized selected food vendors were conveniently selected. For consumers, the procedure for selection was that at the vendors' sites, any other consumer who was willing to be part of the study was sampled and the total number depended on data saturation. Five EHOs were also purposively selected for this study in Accra, Kumasi and Tamale Metropolitan, which are administrative capital cities of Greater Accra, Ashanti and Northern Regions respectively.

The lead researcher conducted the in-depth interviews and took notes of responses with an open-ended checklist in the local Ga and Twi languages. In such open ended interviews actors gave a wide range of information with the liberty to express all their views about a question in all the three locations. However, with the EHOs the English language was used during interviews. With this approach to interviewing, the researcher had the flexibility of asking probing question (Aagaard-Hansen \& Yoder, 2007) to get in-depth knowledge about the issue being discussed.

With food vendors, in-depth interviews often took about two hours, but could last longer in situations where vendors were engaged in activities during the time of visit. During the sales time, for instance, the vendors had to serve their buyers, and this interrupted the interviews. In some instances, the interviews could not be completed in one meeting and so another time had to be scheduled to continue until all the issues were covered. The sample size of food vendors was based on data saturation with repeated information being provided by different vendors. Consumers and EHOs interviews were one time and took about 30 minutes each for consumers and about an hour for the EHOs.

Transcribed qualitative data from individual interviews, and observations were analysed manually. The researcher read transcribed information regularly, de- 
veloped codes from narratives and reported themes that came up along the study research questions. As a way of validating data, actors were contacted on their phones or directly for the confirmation of themes that came out of the analysis, which was also a form of triangulation and validation of the data. The descriptive information about food vendors was analysed with SPSS version 16 software.

Regarding ethical considerations, introductory letters were given to the Metropolitan Directors in charge of street food vending stating the purpose of the study and requesting for their consent and permission to interact with their field staff (EHOs) and food vendors within their metropolises. At the beginning of each interview with any of the actors, the purpose of study was clearly stated and participants' consent was sought. They were informed that they were allowed to discontinue with the interview if they wished so at any point in time of the study. Participants were assured of the confidentiality of any information given and also of their anonymity. Thus, presentation of results and narratives did not bear their names.

\section{Results}

\subsection{Demographic Characteristics of Actors'}

\subsubsection{Age and Experience of Food Vendors}

The demographics of 12 Hausa koko, 19 Waakye and 23 Ga kenkey vendors who participated in the individual in-depth interviews and observations are presented. The Ga kenkey vendors included only two male participants from $\mathrm{Ku}$ masi and Tamale out of the total fifty-four (54) vendors (Table 1) who were interviewed. Thus, the majority (96\%) of the sampled SVLFs vendors were women. The study therefore is in agreement with women's dominance in street food vending. Vendors' ages ranged from 17 to 75 years with majority (56\%) of them falling between ages 25 and 45 . The least experience in food vending was six (6) months and the most were 45 years.

Food vendors enter into food vending based on different objectives and goals and how long they stayed in the business depends on personal objectives and goals. Some could stay over a long time passing on to next generations. This narrative indicates this.

"I have been helping my mother when I was little and now my daughter has also taken up the trade" (Waakye Vendor, Tamale).

Others could leave the business once their goals changed, according to the interactionist perspective. They have the capability to decide on which action to take based on the perceived advantages of their action of vending local foods in the streets. There were no strict rules of entry and exiting food vending. All the vendors had their certificates to operate from the sub-metro offices.

\subsubsection{Educational Background of Food Vendors}

Street foods vending provides employment for people with little education and training (Muinde and Kuria, 2005 and Muyanja et al., 2011). This assertion was 
Table 1. Demographic characteristics of food vendors.

\begin{tabular}{|c|c|c|c|}
\hline Vendors & Female & Males & Total \\
\hline Hausa Koko & 12 & - & 12 \\
\hline Waakye & 19 & - & 19 \\
\hline Ga Kenkey & 21 & 2 & 23 \\
\hline Total & 52 & 2 & 54 \\
\hline Work experience & \multicolumn{3}{|c|}{ Ranges from 6 months to 45 years } \\
\hline Age Categories & Frequency & & Percentage \\
\hline $17-24$ & 13 & & 24 \\
\hline $25-45$ & 30 & & 56 \\
\hline 46 and above & 11 & & 20 \\
\hline Total & 54 & & 100 \\
\hline Educational Level & Frequency & & Percentage \\
\hline No Schooling & 11 & & 20 \\
\hline Basic (Primary, JHS ${ }^{*}$ or MSLC ${ }^{* *}$ ) & 31 & & 57 \\
\hline Secondary and above & 12 & & 22 \\
\hline Total & 54 & & 100 \\
\hline
\end{tabular}

* = Junior High School; ${ }^{* *}=$ Middle School Leaving Certificate.

true in this study. From Table 1, more than half (57\%) of the vendors had their basic education, which included those who had at least two or three years in school and those who had completed primary education including the junior high school (JHS) level or the former middle school system of the country. However, there were some fairly well educated street food vendors.

The research participants of the Ga kenkey vendors interviewed included a retired nurse; a Ga kenkey vendor in Tamale who was preparing for Nursing Training School; and yet another one in Kumasi who was already in the University and helped her mother in Hausa koko vending. About $22 \%$ of vendors had senior secondary education and above, which included the two men in the sample. Still, $20 \%$ had no formal schooling at all.

From these results, two out of every ten vendors had no formal schooling, and more than half had low educational status up to the basic level, indicating a generally low educational level for food vendors. This may affect the uptake of improved practices. However, about two out of ten have higher educational status (secondary and above), which provides an opportunity for such vendors to take up new improved practices in food vending. These findings are closely in agreement with those from Abeokuta, Nigeria where only 18 percent of vendors had no education but 45 percent had at least primary education (Omenu and Aderoju, 2008). 


\subsubsection{Ethnic Background of Food Vendors}

Table 2 shows the ethnic background of all the sampled food vendors for the in-depth interviews. Most vendors of Hausa koko were from the ethnic groups of the five regions of Northern Ghana, comprising Northern, North East, Savannah, Upper East and Upper West Regions. The rest hailed from the Volta Region, the Ashanti Region and neighbouring country Nigeria. Waakye vendors were of the northern tribes of Ghana with one tracing her routes to the Moshe tribe of Burkina Faso.

However, Ga kenkey vendors were of different tribes such as Ashanti, Fanti, Sefwi, Akyem, Ga, Ga Adangbe and Krobo as well as Northern Ghana. For instance, the two men in the sample of Ga kenkey vendors were from Krobo and Ashanti respectively.

\subsubsection{Characteristics and Operations of Environmental Health Officers (EHOs)}

Environmental Health Officers (EHOs) who participated in the in-depth interviews were males with their ages ranging between 36 and 56. The Environmental Health Office is the main regulatory body mandated to regulate activities of all food vendors. They operated under Ghana's Criminal Offences Act 1960 and Metropolitan Assemblies by-laws, which criminalizes the act of selling unwholesome food to the public and sets conditions for the issuance of licenses to people who handled, and sold food and drinks in Hotels, Restaurants, Eating-houses and Chop bars. These Metro Assemblies had Sub-Metros and under these were Town Councils. Town Council areas had men and women officers working under the supervision of a senior officer to ensure proper environmental health within these town council areas, which included activities of all food vendors. They inspect their kitchens and sales points whether at home or at vending sites, and they go through health screening before the food vendors are

Table 2. Food vendors ethnic background.

\begin{tabular}{cccc}
\hline & Hausa koko & Waakye & Ga kenkey \\
\hline Northern Ghana $^{*}$ & 9 & 18 & 7 \\
Ashanti & 1 & - & 3 \\
Ewe & 1 & - & 2 \\
Ga & & & 3 \\
Fanti & & 5 \\
Sefwi & & 1 \\
Akyem & 1 (Nigeria, Hausa) & 1 (Burkina Faso, Moshe) & - \\
Krobo & 12 & 19 & 23 \\
Others & & 1 \\
Total & & & 1 \\
\hline
\end{tabular}

${ }^{*}$ Northern Ghana ethnic groups comprise ethnic groups from Northern, North East, Savana, Upper East and Upper West Regions. 
certified to operate. The health screening is yearly with several monitoring to ensure that safety and hygienic practices are strictly adhered to.

\subsubsection{Characteristics of SVLFs Consumers}

The 18 consumers included 12 males and 6 females with their ages ranging between 16 and 54. They had from basic to tertiary education and of various work backgrounds including, government workers (5), and traders (4), drivers (2), students (2), artisans (3) and the unemployed (2). They had consumed these foods for over 10 years and had it once or twice a week.

\subsection{Actors Perceptions of Challenges of SVLFs}

\subsubsection{Challenges of Street Food Vendors}

Actors were asked about the challenges to the provisioning of safe, nutritious, affordable and local foods for the public. The themes that came out of the responses on the major challenges are indicated in Table 3. Among the vendors, the challenges included lack of adequate capital for expansion, consumer complaints and attitudes as well as issues with the health screening. Health screening issues related to high cost to some vendors, delays in knowing test results as well as double screening resulting in added cost to production. Apart from mandatory screening of vendors by state authority (the Kumasi Metropolitan Assembly), vendors on university campus are again required to undergo a second screening.

Other challenges were the injurious effect of smoke on vendors' health, losses when foods are not all sold and its related issue of limited storage facilities for unsold foods. This issue needs attention because access to good storage facilities for food ingredients is a requirement, which EHOs have to assess before certifying vendors to operate. Unstable prices of food ingredients and competition with other street foods especially fried rice, which vendors perceive as more prestigious to consumers than the local dishes. Vendors are challenged with insecurity of their locations hence preventing them from putting in capital to expand the places of sale. The problem of food spilling was specifically directed to Hausa Koko vendors because of bad polythene bags used for packaging of food for consumers. Keeping their cleanliness while preparing and selling foods under unhygienic conditions was a challenge to vendors. Its related problem was the inconsistency of continual flow of portable water for food preparation. Finally, vendors are not able to form and maintain strong associations.

From the reflections and analyses of results, food vendors' challenges may be categorized into four. Firstly, those related to investment and capital inadequacies for expansion, which includes inadequate capital to expand (they were not willing to commit their limited resources to expanding at unsecured locations where authorities would destroy their investment) and to buy food in bulk for efficient use, high cost of production and losses through unsold foods. Secondly, health issues including injurious effects of smoke, high cost of screening, and delay in knowing screening results. The third category related to keeping safe 
and hygienic environment for the preparation and sale of foods. Finally, their inability to form and maintain functional associations as food vendors

\subsubsection{Challenges of Environmental Health Officers}

The Environmental Health Officers (EHOs) indicated several challenges to ensuring that street vended local foods are locally acceptable, safe, nutritious and affordable for public consumption. These include the despondent behaviour of food vendors despite their continual educations and monitoring. An officer from Kumasi stated that:

Table 3. Actors perceptions of challenges of SVLFs.

\begin{tabular}{|c|c|c|}
\hline Food Vendors & Environmental Health Officers & Consumers \\
\hline $\begin{array}{l}\text { No money to expand our business. We don't } \\
\text { have much capital to buy maize and firewood } \\
\text { to store when they are in season. }\end{array}$ & $\begin{array}{l}\text { We continue to educate food vendors but some do } \\
\text { not change their actions and habits. They often } \\
\text { do their own thing when we are not around. }\end{array}$ & $\begin{array}{l}\text { Concern about the } \\
\text { safety of foods. }\end{array}$ \\
\hline $\begin{array}{l}\text { Consumers complains of the presence of foreign } \\
\text { materials in Waakye with the use of brown rice; } \\
\text { The nature of some customers can be very rude } \\
\text { and requires much patience, meeting all their } \\
\text { needs in order not to lose them. }\end{array}$ & $\begin{array}{l}\text { We are not mobile and are not always able to get } \\
\text { to all the street vendors within our mandate areas; } \\
\text { inadequate office facilities, funds to maintain } \\
\text { existing ones, inadequate staff and training } \\
\text { programs. Low motivation among staff. }\end{array}$ & $\begin{array}{l}\text { Unhygienic cooking and } \\
\text { sales environments. }\end{array}$ \\
\hline $\begin{array}{l}\text { High cost of medical screening; Results of } \\
\text { screening takes too much long in coming. }\end{array}$ & $\begin{array}{l}\text { Food vendors use several other people in food } \\
\text { preparation but do not medically screen all of those } \\
\text { involved with the reason that when those workers are } \\
\text { screened at the cost of the vendor, they go away with } \\
\text { the certificate to be on their own as food vendors. }\end{array}$ & $\begin{array}{l}\text { Low educational } \\
\text { level of vendors. }\end{array}$ \\
\hline $\begin{array}{l}\text { Smoke from the use of firewood } \\
\text { is injurious to our health. }\end{array}$ & $\begin{array}{l}\text { Recalcitrant vendors are prosecuted but there are } \\
\text { problems with the court systems. Most often we } \\
\text { do not have storage facilities to keep exhibits for } \\
\text { presentation at the courts as evidence. }\end{array}$ & $\begin{array}{l}\text { Unwillingness of some vendors } \\
\text { to adopt to improvements } \\
\text { and innovations. }\end{array}$ \\
\hline $\begin{array}{l}\text { Losses from unsold foods with no proper } \\
\text { facilities for storage of food for reuse. }\end{array}$ & $\begin{array}{l}\text { Political interference in the } \\
\text { duties of field staff. }\end{array}$ & $\begin{array}{l}\text { Destruction of traditional methods } \\
\text { of preparation with innovations. }\end{array}$ \\
\hline $\begin{array}{l}\text { Unstable prices of ingredients used } \\
\text { for food preparation. }\end{array}$ & & $\begin{array}{l}\text { Poor implementation and } \\
\text { enforcement of regulations } \\
\text { and standards by the } \\
\text { required authorities. }\end{array}$ \\
\hline $\begin{array}{l}\text { Stand in competition with other street foods especially } \\
\text { fried rice that some people think is more prestigious. }\end{array}$ & & $\begin{array}{l}\text { Increased cost of improvement } \\
\text { transferred to consumers. }\end{array}$ \\
\hline $\begin{array}{l}\text { Problems with securing our locations: "we cannot } \\
\text { make bigger kiosk, we are afraid that authorities will } \\
\text { remove it when we have spent so much in making it" }\end{array}$ & & $\begin{array}{l}\text { Financial constraints on the part } \\
\text { of food vendors to innovate and } \\
\text { improve on their activities. }\end{array}$ \\
\hline \multicolumn{3}{|l|}{$\begin{array}{l}\text { Keeping our cleanliness is one challenge to us as } \\
\text { food vendors; not always preparing the food } \\
\text { under hygienic conditions. Inadequate supply } \\
\text { of portable water (not continually flowing). }\end{array}$} \\
\hline Inability to $\mathrm{m}$ & & \\
\hline
\end{tabular}


"We continue to educate food vendors but some do not change their actions and habits... they do their own thing when we are not around. You know Madam... we cannot always be there" (EHO, Kumasi).

Another challenge that EHOs mentioned is in relation to certifying all those involved in preparation and sale of street foods. One officer in Accra said this:

"Food vendors involve several other persons in their food preparation and vending activities but are not willing to screen all such workers".

Their reasons relate to the high cost involved and the unfaithfulness of some of such workers, who leave them after obtaining the health certificate at the cost of their employers to start their own food vending ventures. Another challenge is with recalcitrant vendors who are prosecuted but due to the problems with the court systems, get away to continue with their unmanageable behaviours. Most often, the offices of the regulatory officials do not have storage facilities and they are unable to keep their exhibits for presentation at the courts for evidence. Again, there is low motivation among officers, there is inadequate facilities and logistics to work effectively, lack of funds to maintain existing ones, inadequate staffing and political interference in the work which challenges their effective regulation of street food vendors.

Thus, EHOs challenges are grouped into two, ensuring food vendors compliance to safe and hygienic practices in the preparation and sale of SVLFs and enhancing regulations and enforcement of their activities. This latter category is related to institutional and intra-institutional challenges that constraints their efforts in ensuring that foods are safe for public consumption (Osei Mensah et al., 2016).

\subsubsection{Consumers Perceived Challenges of Street Vended Foods}

Consumers perceived challenges of SVLFs included vendors low educational level, making them incompetent, lacking the technical knowhow in providing safe food for public consumption and their unwillingness to change and adapt to improving situations and innovations. They were worried about the safety of foods with the use of chemicals for growing vegetables and the unhygienic cooking and sale environments within which food vendors operated. A consumer in Accra indicates some of these concerns:

"The vegetables are good but the concern is with the chemical sprayed on them... it is a challenge but we trust our vendors to provide clean foods to us..." (Waakye Consumer, Accra).

Nevertheless, individual in-depth interviews with vendors showed their willingness to innovate if they had enough capital, which represented the symbolic interactionism's perspective that allowed for changes and innovations by individuals. A Waakye vendor in Accra stated that:

“...You see this my place madam, I have enough space to expand but I 
don't have enough money, see I am taking care of the children... If I have the opportunity, I will make it a nice place to attract more customers...”.

Therefore, the perception of consumers on food vendors' unwillingness to change may be due to financial constraints. In addition to the financial constraint, the low level of education, perceived incompetency among some food vendors, which was also a challenge may exacerbate the unwillingness of vendors to accept changes and innovations. Some consumers also opined that improvements in food preparation had diluted the local food preparation methods, the local taste of foods and the general food tradition. However, a Waakye vendor from Tamale noted that:

"Even with these improvements we still use our traditional processes of making Waakye, the local rice, the beans (cowpea) and the stalk to give it colour, they are still our local food, just improved you know, more people are buying it, see the students... and we should present it just like the fried rice people do" (Waakye Vendor, Tamale).

Other challenges consumers mentioned were poor implementation and enforcement of regulations and standards by the relevant authorities, increased cost of improvement transferred to consumers and unhygienic kitchens and sales points. The regulatory body that was responsible for the implementation and enforcement of regulations and standards to ensure hygienic kitchens and sales points in general was constrained by limited resource as noted above. In relation to the cost of innovations being transferred to consumers, one had to pay for quality especially when it came to food. The challenge thus, was the increased cost of food in relation to the income levels of consumers. In sum, consumers' challenges may also be grouped into the incompetence of vendors because of their low educational level, safety and hygienic concerns, and the poor implementation and enforcement of safety and hygiene regulations.

\subsection{Actors Perceptions of Opportunities to Improve SVLFs}

Despite the several challenges confronting food vending noted by these actors, they mentioned some opportunities available for the improvement of SVLFs. All the actors were of the opinion that food vendors had an opportunity to deliver healthier, safer, and more nutritious and more convenient foods to the public. Some vendors noted the following:

"We have the opportunity to follow all the regulations of the EHOs, they trouble us though but it is for the good of our customers so that we give them safe and healthy foods always" (Hausa koko Vendor, Kumasi).

"I do my best to make sure that I prepare the food well, make it nutritious and tasty for my customers. You know, I can add several other sauces to make my Ga kenkey more nutritious... but..." (Ga kenkey Vendor, Tamale). 
This could be done through continual education of food vendors regularly on food safety and hygiene issues. There is an opportunity to improve SVLFs vending through the effective enforcement of regulations and adherence to standards. If challenges are to be turned into opportunities then the local authorities have the opportunity to equip the regulatory officers with all the needed institutional and logistic support to ensure that vendors provide safe foods to the public.

One EHO indicated this:

"Opportunity for the vendors is to improve upon their packaging. Improve upon their organized service outlets and sales point. Branding of the local foods could be an ultimate goal for vendors" (EHO, Tamale).

Other opportunities were the sustained consumers' patronage, global acceptance of these local dishes, better packaging and branding of local dishes as well as the formation of groups or associations to access resources such as loans, knowledge and to advertise their food products etc. Food vendors had the opportunity to improve the preparation and sale environment of local foods and it could be a source of employment for competent people (from the Polytechnics and Universities who studied food and nutrition and its related subjects). All these opportunities provide an avenue for all actors in the SVLFs to improve on their activities to ensure that foods are safe, nutritious and affordable and of local acceptance to the consuming public. This would require continual education of all such key actors.

\section{Discussions}

Street vending in general is faced with several constraints (FAO, 2007; Karg et al., 2010; Bruhn et al., 2012; Osei Mensah et al., 2016) and this study confirms such findings. Consumers found the low educational levels of vendors to be a challenge and it corroborates with other findings (Otoo et al., 2011; FAO, 2016; Habib, 2016). This low level of education and unwillingness to change on the part of vendors as perceived by consumers is an attitudinal issue and may persist even among those with fairly high education. If the mind-set is not right despite the level of education the safe provisioning of street foods may be compromised. Thus, from the results presented, though about $20 \%$ of respondents did not have any education, most of them had their basic education and about $20 \%$ also had secondary to tertiary educational levels confirming the work of Omenu \& Aderoju (2008) and Okojie \& Isah (2014). This however, creates an opportunity for such vendors to learn and to practice the safe and hygienic knowledge they are thought. Again, food vendors learned on the trade from their mothers, other relations and as assistants for other food vendors and may not require higher educational levels to go into food vending (Haleegoah et al., 2016). For the assistants who learn on the trade, for instance, they go into food vending on their own, when they have enough capital to start. They brought the knowledge acquired while working as assistants to bear in their work. Thus, the opportunity for con- 
tinual education of food vendors is critical for the provisioning of safe, nutritious and affordable local dishes to the public.

Food vendors also introduced some innovations to improve on the food supply in urban areas. Results from this study showed that food vendors were willing to innovate and to improve their vending operations if they had the financial means. Both consumers and vendors mentioned this issue of financial challenge. This implied that, if food vendors' capacities were built, and were empowered through capacity building in financial management and provision of soft loans, they would innovate and improve upon their food vending operations. Osei Mensah et al. (2016) found that inadequate managerial skills and financial constraints had negative effects on the gross margin ratio between their baseline and follow-up periods.

The problem of not being able to sustain associations had been identified as a challenge to food vending (Karg et al., 2010; Nicolò, 2012), which our findings corroborates. In the in-depth interviews with food vendors and EHOs, they all knew the benefits of associations. However, several attempts made into organizing them into associations had failed. Studies had shown that only few vendors were known to be part of an association (Nicolò, 2012; FAO, 2016). Karg et al. (2010) noted that the lack of organizational goals was the main reasons for these associations' not thriving among food vendors.

Touching on the destruction of the traditional ways of preparing SVLFs through innovations, as mentioned by some consumers, they would prefer the traditional way of doing things. Through the transfer of skill and knowledge of local food preparation and vending, the women maintained the identity of foods, making them local despite the innovations to improve upon their safety and nutrition.

All actors identified the challenge of keeping safety and hygienic environment, which has widely been studied (Sackey et al., 2001; Mensah et al., 2002; Ayeh-Kumi et al., 2009; Ackah et al., 2011; Micah et al., 2012; Okojie \& Isah, 2014). Monney et al. (2014), found that overall compliance to food hygiene and safety principles was marginally good with difference between Bibiani and Dormaa-Ahenkro in the Western and the now Bono regions in Ghana. Their identified challenging aspects of weak institutional capacities, logistical constraints, in consistent local by-laws and duplicating institutional responsibilities are corroborated in this study where the EHOs have issues with their institutional support and the judiciary system.

The most common problem with street vending is issues with local authorities (FAO, 2007; Spire \& Choplin, 2018). In this study, the issue relates to the medical screening for yearly certification, which often creates conflicts between the EHOs and food vendors. We note, however, that the double screening of some vendors who also operated at the University, though perceived as a problem to such vendors, is an assurance of the health status of such vendors and that they would provide safe foods for the public. Problem with local authorities also re- 
lates to the unsecured locations preventing food vendors to invest money to expand their vending areas. This conflict occurs when the local authorities remove structures from unapproved sites. The EHOs, city engineers and city planners could collaborate to designate appropriate areas within the towns for local food vending which could enhance compliance of safe and environmental regulations. The EHOs also complained about how vendors go back to their old practices when they were not around despite all the training given them in maintaining safe and hygienic environments. Nevertheless, food vendors have been shown to have good overall compliance to food hygiene and safety principles (Muinde \& Kuria, 2005; Muyanja et al., 2011; Ackah et al., 2011; Monney et al., 2014).

\section{Conclusion}

This paper examined actors' challenges and opportunities to improve SVLFs to be safe, nutritious, affordable and of local preference in Ghana. Three main actors (food vendors, EHOs and consumers) of three specific local dishes, (Hausa koko, Waakye and Ga kenkey) responded to questions on the challenges and opportunities to improve these foods in urban areas during in-depth interviews.

The results show several challenges that relate to the safety and hygienic conditions at preparation and sale environments, and issues with the local regulatory authorities, inadequate capital, low educational level of vendors, health issues of vendors and their inability to maintain strong associations. The implications of these challenges to sustaining SVLFs may be numerous. One of such is the challenge to ensure the safety of street foods. If actors are constrained in maintaining the safety of SVLFs, then the idea that street foods are safe is questionable. This demands that measures are put in place to safeguard the health of food vendors and consumers. Measures such as continual education of food vendors and consumers on their safety and that of foods, and institutional support and motivation for regulatory bodies would help sustain the SVLFs in urban areas.

Several opportunities prevailed for the improvement of SVLFs such as continual education for all actors, existence of environmental health officers and local authorities, and the effective work of these local authorities when they are adequately resourced for their regulatory activities. Other opportunities such as sustained consumers' patronage, global acceptance of these local dishes and availability of better packaging and branding techniques for local dishes prevail for the provisioning of these SVLFs. We conclude that amidst the challenges, efficient and effective collaboration between all stakeholders and relevant institutions could offer the vendors an opportunity and capacity to provide healthy, affordable and preferred local dishes of cultural value to the public.

\section{Acknowledgements}

We would like to acknowledge all the food vendors, environmental health officers and consumers who provided the information for the realisation of this study. 


\section{Conflicts of Interest}

The authors declare no conflicts of interest regarding the publication of this paper.

\section{References}

Aagaard-Hansen, J., \& Yoder, P. (2007). Buying Research: A Customers' Guide. Copenhagen: DBL-Centre for Health Research and Development, University of Copenhagen.

Ackah, M., Gyamfi, E. T., Anim, A. K., Osei, J., Hansen, J. K., \& Agyemang, O. (2011). Socio-Economic Profile, Knowledge of Hygiene and Food Safety Practices among Street-Food Vendors in some parts of Accra-Ghana. Internet Journal of Food Safety, 13, 191-197.

Aksan, N., Kısac, B., Aydın, M., \& Demirbuken, S. (2009). Symbolic Interaction Theory. Procedia Social and Behavioral Sciences 1 (pp. 902-904). World Conference on Educational Sciences 2009. https://doi.org/10.1016/j.sbspro.2009.01.160

Ayeh-Kumi, P. F., Quarcoo, S., Kwakye Nuako, G., Kretchy, J. P., Osafo-Katanka, A., \& Mortu, S. (2009). Prevalence of Intestinal Parasitic Infections among Food Vendors in Accra, Ghana. Journal of Tropical Medical Parasitology, 32, 1-8.

Baxter, P., \& Jack, S. (2008). Qualitative Case Study Methodology: Study Design and I Plementation for Novice Researchers. The Qualitative Report, 13, 544-559. http://www.nova.edu/ssss/QR/QR13-4/baxter.pdf

Bellia, C., Pilato, M., \& Seraphin, H. (2016). Street Food and Food Safety: A Driver for Tourism? Calitatea, 17, 20-27.

Bruhn, M., Karlan, D., \& Schoar, A (2012). The Impact of Consulting Services on Small and Medium Enterprises: Evidence from a Randomized Trial in Mexico. Yale Economics Department Working Paper No. 100. https://doi.org/10.2139/ssrn.2010710

Chukuezi, C. O. (2010). Food Safety and Hygienic Practices of Street Food Vendors in Owerri, Nigeria. Studies in Sociology of Science, 1, 50-57. http://www.cscanada.net http://www.cscanada.org

Dorresteijn, H. M. (2014). Global Dynamics and Empowerment of the Local Street Food Network: A Case Study on the Ghana Traditional Caterers Association in Accra. MSc Thesis, Wageningen: Wageningen University and Research Centre.

FAO (2007). Promises and Challenges of the Informal Food Sector in Developing Countries. Rome: S. Simon.

FAO (2016). Street Food in Urban Ghana. In S. Marras, \& M. AgBendech (Eds.), $A$ Desktop Review and Analysis of Findings and Recommendations from Existing Literature.

Forkuor, J. B., Akuoko, K. O., Yeboah, E. H., Rheinländer, T., \& Samuelsen, H. (2016). Food Vending among Men in Kumasi: Socio-Cultural Advantages, Constraints, and Coping Strategies. International Journal of Social Science Studies, 4, 94-102. https://doi.org/10.11114/ijsss.v4i2.1278

Habib, K. R. (2016). Understanding Challenges Faced by Street Food Vendors to Maintain Street Food Hygiene in Dhaka City. Journal of Food and Nutrition Sciences, 4, 78-85. https://doi.org/10.11648/j.jfns.20160404.11

Haleegoah, J., Ruivenkamp, G., Essegbey, G., Frempong, G., \& Jongerden, J. (2015). Street-Vended Local Food Systems Actors Perceptions on Safety in Urban Ghana: The Case of Hausa Koko, Waakye and Ga Kenkey. Advances in Applied Sociology, 5, 134-145. https://doi.org/10.4236/aasoci.2015.54013 
Haleegoah, J., Ruivenkamp, G., Essegbey, G., Frempong, G., \& Jongerden, J. (2016). Street-Vended Local Foods Transformation: The Case of Hausa Koko, Waakye and Ga Kenkeyin Urban Ghana. Advances in Applied Sociology, 6, 90-100. https://doi.org/10.4236/aasoci.2016.63009

Hiamey, S. E., \& Hiamey, G. A. (2018). Street Food Consumption in a Ghanaian Metropolis: The Concerns Determining Consumption and Non-Consumption. Food Control, 92, 121-127. https://doi.org/10.1016/j.foodcont.2018.04.034

Karg, H., Drechsel, P., Amoah, P., \& Jeitler, R. (2010). Facilitating the Adoption of Food-Safety Interventions in the Street-Food Sector and on Farms. Astewater Irrigation, 319, 1-319.

Martey, E., Annin, K., Attoh, C., Wiredu, A. N., Etwire, P. M., \& Al-Hassan, R. M. (2013). Performance and Constraints of Small Scale Enterprises in the Accra Metropolitan Area of Ghana. European Journal of Business and Management, 5, 83-93.

Mensah, P., Yebaoh-Manu, D., Owusu-Darko, K., \& Ablordey, A. (2002). Street Foods in Accra, Ghana: How Safe Are They? Bulletin of the World Health Organization, 80, 546-554.

Micah, E. B., Colecraft, F. K., Lartey, A., Aryeetey, R., \& Marquis, G. S. (2012). Street Foods Contribute to Nutrient Intakes among Children from Rural Communities in Winneba and Techiman Municipalities, Ghana. African Journal of Food Agriculture, Nutrition and Development, 12, 5789-5801.

Monney, I., Agyei, D., Badzi, S. E., Campaore, P., \& Nyaw, S. (2014). Food Hygiene and Safety Practices among Street Food Vendors: An Assessment of Compliance, Institutional and Legislative Framework in Ghana. Food and Public Health, 4, 306-315.

Muinde, O. K., \& Kuria, E. (2005). Hygienic and Sanitary Practices of Vendors of Street Foods in Nairobi, Kenya. African Journal of Food Agriculture and Nutritional Development, 5, 1-14.

Muyanja, C., Nayiga, L., Namugumya, B., \& Nasinyama, G. (2011). Practices, Knowledge and Risk Factors of Street Food Vendors in Uganda. Food Control, 22, 1551-1558. https://doi.org/10.1016/j.foodcont.2011.01.016

Nicolò, G. (2012). Report on the Study of Street Food Vending in Ghana 2012. Accra (Ghana): FAO RAF, Unpublished.

Okojie, P. W., \& Isah, E. C. (2014). Sanitary Conditions of Food Vending Sites and Food Handling Practices of Street Food Vendors in Benin City, Nigeria: Implication for Food Hygiene and Safety. Journal of Environmental and Public Health, 2014, Article ID: 701316. https://doi.org/10.1155/2014/701316

Omenu, A. M., \& Aderoju, S. T. (2008). Food Safety Knowledge and Practices of Street Food Vendors in the City of Abeokuta, Nigeria. Food Control, 19, 396-402. https://doi.org/10.1016/j.foodcont.2007.04.021

Osei Mensah, J., Ohene-Yankyera, K., \& Aidoo, R. (2016). Constraints to Growth of Micro and Small-Scale Enterprises in Ghana: A Case of Street Food Enterprises. Journal of Development and Agricultural Economics, 8, 241-250. https://doi.org/10.5897/JDAE2016-0732

Otoo, M., Fulton, J., Ibro, G., \& Lowenberg-DeBoer, J. (2011). Women Entrepreneurship in West Africa: The Cowpea Street Food Sector in Niger and Ghana. Journal of Developmental Entrepreneurship, 16, 37-63. https://doi.org/10.1142/S1084946711001732

Quader, S. M., \& Abdullah, M. N. (2008). Constraints to SMEs: A Rotated Factor Analysis Approach. South Asian Stud, 2, 334-350.

Rheinländer, T., Olsen, M., Bakang, J. A., Takyi, H., Konradsen, F., \& Samuelsen, H. 
(2008). Keeping up Appearances: Perceptions of Street Food Safety in Urban Kumasi, Ghana. Journal of Urban Health: Bulletin of the New York Academy of Medicine, 85, 952-964. https://doi.org/10.1007/s11524-008-9318-3

Sackey, B. A., Mensah, P., Collison, E., \& Sakyi-Dawson, E. (2001). Campylobacter, Salmonella, Shigella and Escherichia Coli in Live and Dressed Poultry from Metropolitan Accra. International Journal of Food Microbiology, 71, 21-28. https://doi.org/10.1016/S0168-1605(01)00595-5

Sefa-Dedeh, S., Sakyi-Dawson, E., Johnson, P. N., \& Sarpong, G. (2009). Consultants "Food Safety in Ghana: A Situational Analysis Report". Accra, Ghana.

Seferiadis, A. A. (2009). Food Security for the Urban Poor and Street-Food in Accra. Strengthening the Local Networks. MSC Thesis, Amsterdam: Vrije Universiteit Amsterdam. Unpublished.

Spire, A., \& Choplin, A. (2018). Street Vendors Facing Urban Beautification in Accra (Ghana): Eviction, Relocation and Formalization. Articulo-Journal of Urban Research, 1-18. https://doi.org/10.4000/articulo.3443

World Health Organization (WHO) (2006). AFRO Food Safety Newsletter. WHO Food Safety (FOS) Issue No. 2, 1-10. 